\title{
Surface and subsurface engineering geological mapping for empirical designs of excavation method and support system of Tunnel 6 of Jakarta-Bandung high speed railway, Indonesia
}

\author{
Octavika Malda ${ }^{1}$ I Gde Budi Indrawan ${ }^{1 *}$, and Akmaluddin Akmaluddin ${ }^{1}$ \\ ${ }^{1}$ Gadjah Mada University, Department of Geological Engineering, Jl. Grafika Bulaksumur No.2, Yogyakarta, Indonesia
}

\begin{abstract}
Empirical design of support system at the Tunnel 6 of the Jakarta - Bandung high-speed railway was based on the Basic Quality (BQ) system, which had not been adopted in Indonesia. This research was carried out to better understand the rock mass quality at the tunnel construction site by comparing rock mass quality determined by the BQ system to that determined by two more popular rock mass classifications, namely the Geological Strength Index (GSI) and Rock Mass Rating (RMR). Surface and subsurface engineering geological mapping were carried out and tunnel excavation method and support system were proposed. The engineering geological model of the BQ, GSI, and RMR systems showed that the sedimentary rock masses of the Miocene Jatiluhur Formation generally had poor to very poor quality, while those of the Quaternary Volcanic Formation had very poor to good quality. Based on the RMR, the stand-up time values of the sedimentary rock masses were predicted to be relatively low as compared with those of the Quaternary Volcanic Formation, implying requirement of a relatively quick support system installation after excavation. In general, a combination of systematic bolt, shotcrete and steel ribs is the recommended support system for this tunnel.
\end{abstract}

\section{Introduction}

Tunnel 6 is the longest of the 13 tunnels of the JakartaBandung high-speed railway. Tunnel 6 stretches for 4.4 $\mathrm{km}$ and crosses the administrative area of West Java Province: Purwakarta Regency on the inlet side and West Bandung Regency on the outlet side (Fig. 1). Tunnel 6 was built using the NATM method with a horseshoe geometry having dimensions of 13 meters high, 14 meters wide and $\pm 25 \%$ trace grade from the inlet to the outlet. The morphology at the tunnel location is dominated by undulating hills with the ridge direction generally east-west and partly northeastsouthwest.

The investigation data used in the construction of this tunnel is in the form of surface geological mapping activities, core samples of 16 drilling locations and 4 face mapping data. The rock composition at the tunnel construction site is volcanic rock from the Quartenary Formation of Older Volcanic Product (Qob) which is overlay unconformity with the fine-grained clastic sedimentary rocks of the inserts of the Miocene Jatiluhur Formation Sandstones (Mdm)[1]. The angular unconformity relationship between the two formations at the study area shows the complexity of the geological conditions so that accuracy is needed to develop geological and engineering geological models in this work. This condition becomes more complicated where the lateral distribution of the rock on the surface is volcanic from Qob Formation, while at the elevation of the tunnel It is a fine-grained clastic sedimentary rock from the Jatiluhur Formation which is very limited exposed on the surface.

The existing investigative data is used as one of the variables in determining the quality condition of the rock mass. The rock mass quality classification system is a very useful instrument for the initial design stage of a project when the available information is limited[2]. The rock mass quality classification system used in this project is the BQ classification system, which is relatively new in Indonesia. In order to build a model regarding the condition of rock mass quality it is important to use more than one classification system in order to describe the composition and characteristics of the rock mass from various perspectives to provide a proper initial estimate of the support system of the tunnel[2]. The rock mass classification used in this study is the RMR89 and GSI. The model built from a rock mass classification system is basically an empirical model, however it is very useful in the early stages of a tunnel construction work[2]. Several rock parameters were obtained from direct field test results with reference to the field direct method test from ISRM 1981[3]. It is expected that the results of this research improve understanding the use of BQ system for determination of rock mass quality, particularly in tunnelling projects in Indonesia.

\footnotetext{
* Corresponding author: igbindrawan@ugm.ac.id
} 


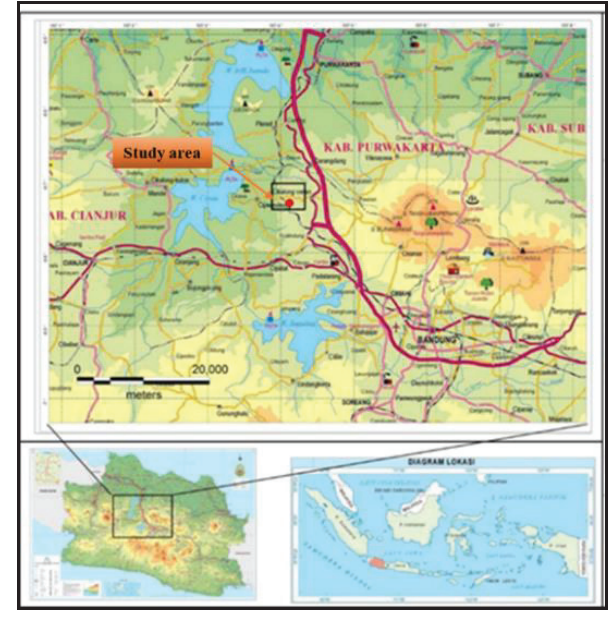

Fig. 1. Research area[4]

\section{Methodology}

In this study, the type of data is divided into 2 data models, surface data and subsurface data, both of which serve as variables in forming geological models, classification of rock mass quality, engineering geological models and empirical references to determine the initial design of the tunnel support system, standup time and determining the excavation method that will be used in the construction of the tunnel 6.

Surface data from the results of surface mapping are in the form of outcrop data, lithological types, discontinuity measurement data and classification of surface rock mass quality. The subsurface data is in the form of drilling data as many as 16 drill holes, 4 face mapping locations. Weathering rate parameter data of surface and subsurface rocks refers to ISRM[3]. The rock strength parameter refers to the direct field test method Hoek., et al[5]. The flow of this study can be seen in Figure 2.

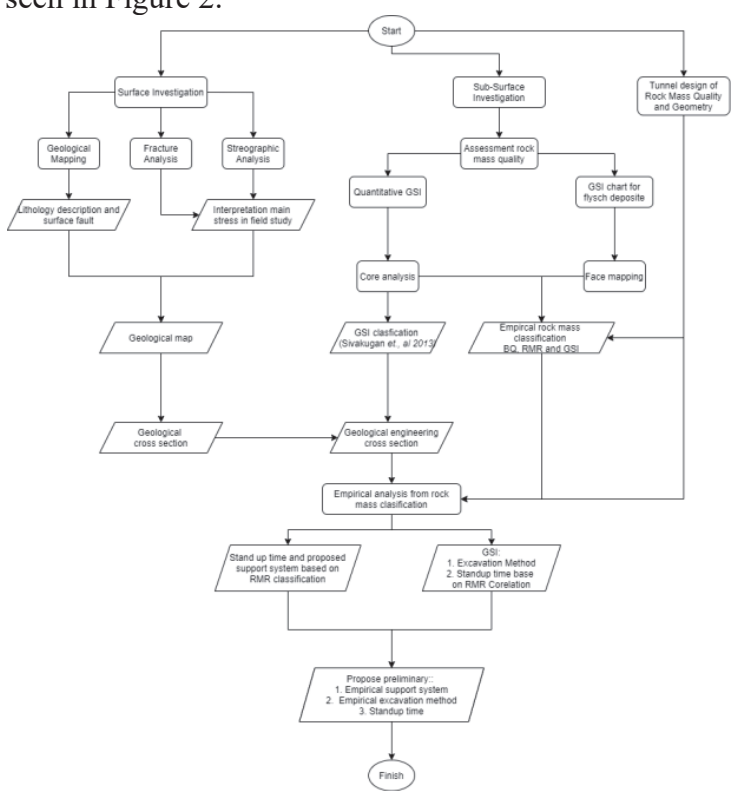

\section{Classification of rock mass quality}

In this paper, there are 3 classifications that will be used, it is the BQ system classification[6], RMR89[7] and GSI [8-11].

\subsection{Basic Quality (BQ) system}

Rock mass classification Basic Quality (BQ) system is a rock mass classification system that is mandatory in China[12]. Referring to the code for design of railway tunnel: TB 10003-2016[6], the BQ value is determined by two parameters: rock strength (Rc) and rock mass integrity (Kv), as shown in Eq. (1):

$$
B Q=100+3 R c+250 K v
$$

Where Rc is the value of saturated UCS and $\mathrm{Kv}$ is the value of elastic longitudinal wave velocity of rock mass and of intact rock. To provide more actual rock mass quality data the basic BQ value (eq. 1) needs to be adjusted as follows: three coefficients, groundwater condition $\mathrm{K} 1$, orientation of weakness zone related to the excavation $\mathrm{K} 2$ and in-situ stress condition $\mathrm{K} 3$, are considered to corrected BQ value as[6]:

$$
[B Q]=B Q-100(K 1+K 2+K 3)
$$

\subsection{Rock Mass Ratting (RMR) system}

RMR has changed historically at least 5 times so it is important to include the year or version of the RMR that is used as a reference in a study[13]. This study uses the 1989 version of the RMR classification[7]. RMR89 has 6 parameters and each parameter has a different value from the sum of these values, the rating is obtained for a rock mass, the six parameters are the compressive strength value of intact rock (UCS/ Point Load), RQD, discontinuous spacing, discontinuous conditions, groundwater conditions at the measurement location and the orientation of the discontinuous plane to the measurement location.

\subsection{Geological Strength Index (GSI)}

The essence of the GSI is a careful description of engineering geology of the rock mass, which is essentially qualitative, because it is believed that a amount of fracture (joint) largely meant for weak rock mass conditions and complex[14]. The determination of the GSI value in the field is based on the basic GSI chart proposed by using two variable, structural parameters on the surface and the quality of the surface of the outcrop[7]. In this study also used the GSI classification table developed to assess a rock mass from tubidite or flysch deposits[11]. As for determining the value of GSI of the drilling results based on the method of quantification of GSI based on two factors: joint condition from RMR89 and value of $0.5 \mathrm{RQD}[9]$.

Fig. 2. Research flow diagram 


\section{Geology study area}

The geological conditions of the research location on the surface are dominated by volcanic rocks from the Qob Formation in the form of volcanic breccias, laharic breccias and several locations where andesite lava is present. The Qob Formation overlaps the Mdm Formation which is generally fine-grained sedimentary rocks such as marl, shale, claystone with sandstone intercalated which are deep sea turbidite deposits or flysch[15].

Based on the results of surface geological mapping, the position of the rocks that make up the Mdm Formation has a dip direction to the south with a varying angle between $30^{\circ}-55^{\circ}$ which shows the relationship of angular unconformity with the Qob formation at the top. The reconstruction of the surface geological model based on drilling data, face mapping and surface mapping shows that the tunnel elevation is generally located in the sedimentary rock units of the Mdm formation and partly in the Qob formation (Fig. 3 and 9).

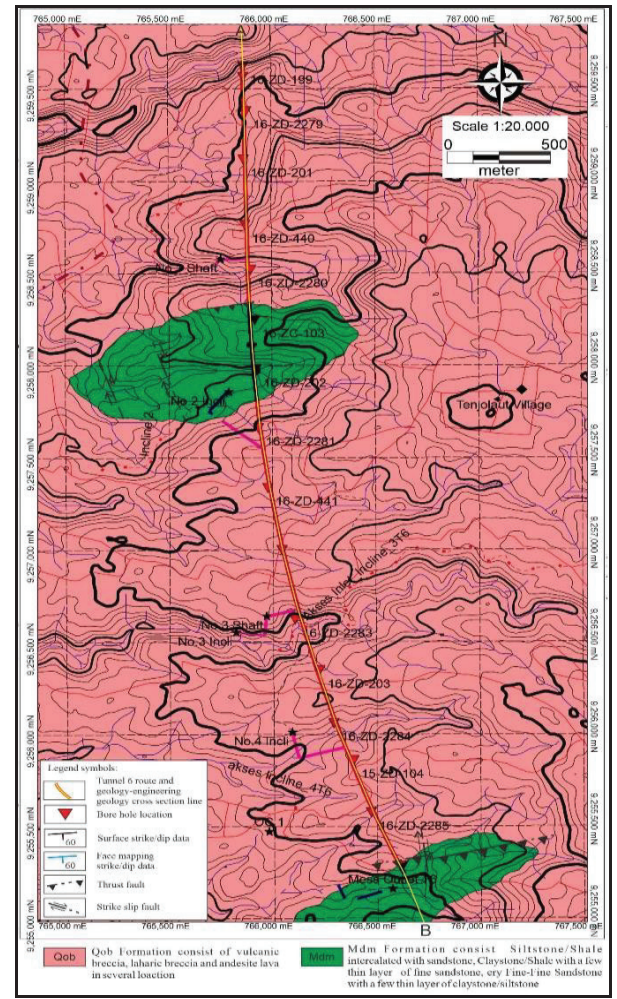

Fig. 3. Geological map of study area

\subsection{Lithology}

The results of surface geological mapping show the Qob Formation unit consisted of:

1. Volcanic breccias with fragment supported fragment compositions in the form of igneous andesite rock and a small matrix of coarse sand (Fig. 4a).

2. The fundamental difference between laharic breccias and volcanic breccias is the difference in the amount of fragments where in the laharic breccias the fragments are still floating andesite rocks on a medium-coarse sand matrix, the size of the fragments is smaller than volcanic breccias (Fig. 4b).

3. In this formation there are several lava andesite (Fig.4c).

The Mdm formation at the study site consists of claystone, marl, calcareous shale with intercalated sandstones. This formation shows the characteristics of deep sea deposits or flysch with the appearance of graded bedding sedimentary structures and pelagic claystone (Fig.4d)[16].

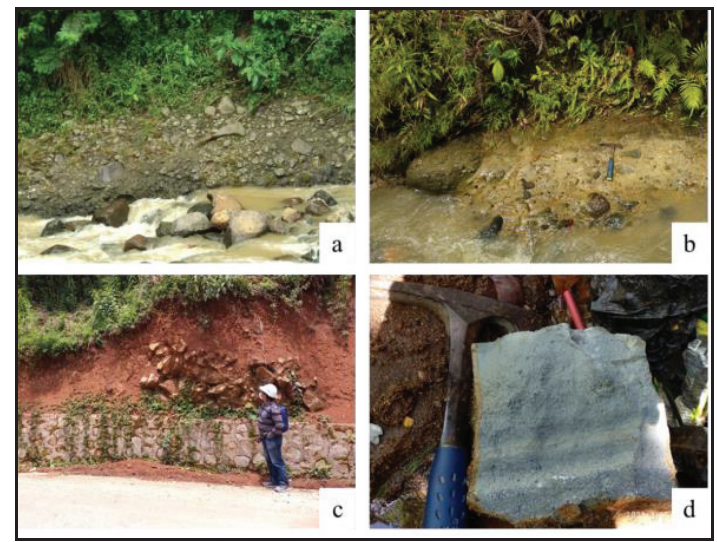

Fig. 4. Example of outcrops in study area figure a-c lithology from Qob formation and sandstone from Mdm formation; a. volcanic breccia, b. laharic breccia, c. lava andesite and $d$. sandstone with graded bedding structure

\subsection{Geological structure}

From the appearance of aerial imagery or the National Digital Elevation Models (DEMNas), the research locations generally have a general direction of relative West-East alignment (Fig. 5). The direction of this ridge reflects the direction of the "Java pattern" structure which reflects the direction of the main stress influenced by the subduction of the Indian plate which is in the south of Java[17]. This is also reflected in the position of the rock in a direction to the south, thrust faults with a plane position N065 ${ }^{\circ} \mathrm{E} / 68^{\circ}$ (Fig. 5) and the stereographic analysis of the fractures in the sandstone layer of the Mdm formation which shows the direction of the main stresses $\mathrm{N} 329 \mathrm{E}^{\circ}$ and $\mathrm{N} 147^{\circ} \mathrm{E}$ or relative north-south (Fig. 6).

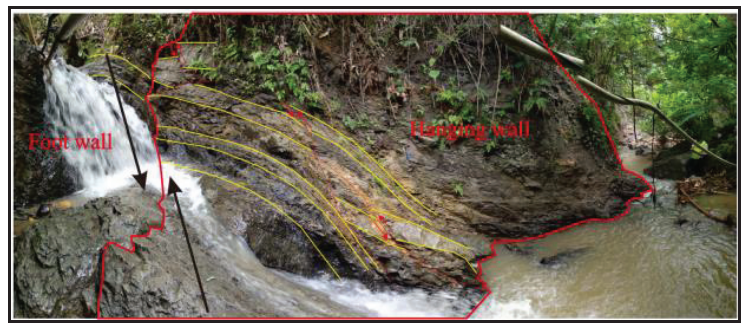

Fig. 5. Dander thrust fault one of the supporting data in forming a geological and engineering geology model 


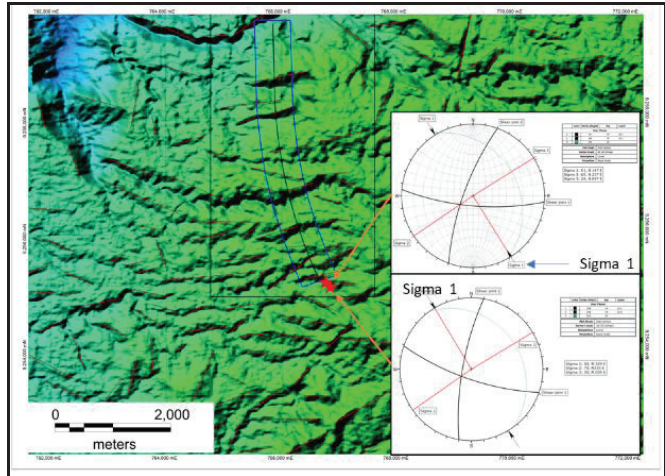

Fig. 6. Lineament and stereographic analyses indicate the main tectonic stress has a relative north to south direction

\section{Engineering geology of study area}

With geological conditions that are quite complex and the data on outcrops are limited, it is necessary to correlate and calibrate the surface and subsurface conditions.

\subsection{Surface condition}

The quality condition of the surface rock mass uses the GSI basic chart and the GSI chart for heterogeneous rock masses such as flysch deposits. The use of the GSI classification in this study is because this classification is easier to use, considers geological conditions and provides the required geological information [7].

There are several outcrops that are considered to still reflect the quality of the rock mass in each formation at the research location. The Qob formation is as follows:

1. Volcanic breccias (Fig.4a), generally have moderate weathered to highly weathered weathering rates refer to ISRM, 1981[3]. Surface structure is disintegrated, GSI value is based on basic chart 25-30.

2. Laharic breccias (Fig.4b), weathering rates are generally highly weathered according to ISRM, 1981[3]. The surface structure is disintegrated, the GSI value is based on the basic chart 20-25.

3. Andesite lava (Fig.4c), surface conditions are generally in the form of rock blocks surrounded by red weathered sandy material. High weathered weathering conditions refer to ISRM, 1981[3]. Very blocky surface structure with join sets of 4 to more than 4, GSI values range from 33-38.

The Mdm Formation is dominated by claystone outcrops with intercalated of sand, siltstone and shale with rock mass qualities as follows:

1. Shale with thin inserts of sandstones (Fig. 7) weathering conditions of highly weathered rocks with poor discontinuous surface conditions. The structure and composition of the outcrop entered into type IV of the GSI chart for heterogeneous rocks or flysch deposits, GSI values 25-30.
2. The outcrop is an thrust fault zone with a composition dominated by claystone with several layers of fine-very fine sandstone based on plotting on chart IV of the GSI chart for heterogeneous rocks or flysch deposits, GSI values $25-30$ (Fig. 6).
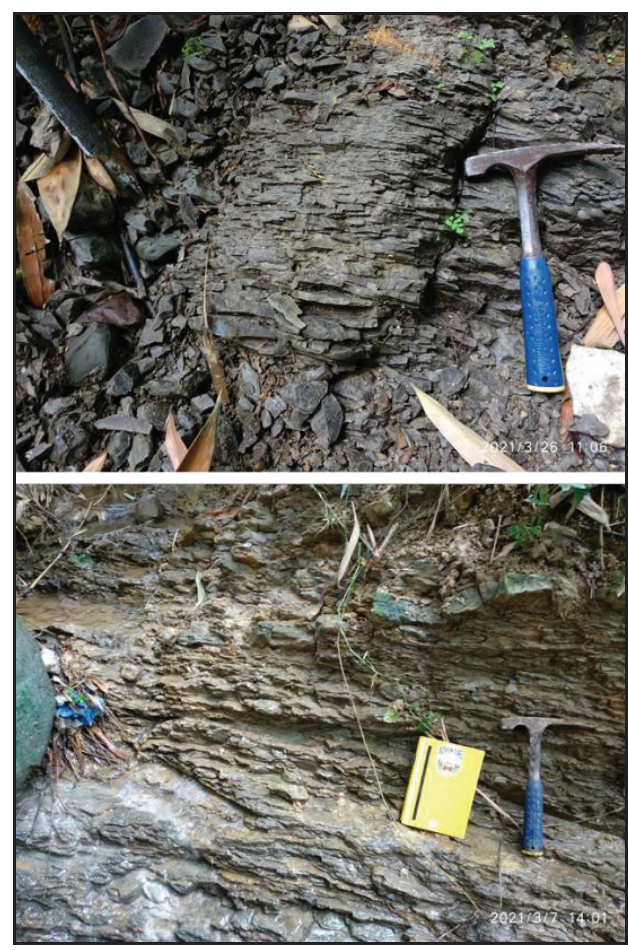

Fig. 7. Outcrops of claystone/shale with a few thin layer of fine sandstone indicated flysch deposite product.

\subsection{Sub-surface condition}

The minimal amount of surface outcrops, weathering conditions on the outcrops due to climate and tunnel elevations that are deep or far from the surface, so it is necessary to interpret subsurface conditions using data from core drilling results. The ongoing development process allows additional data collection of face mapping activities from within the tunnel location as additional information that is essential for calibrating surface and subsurface models.

From the 16 existing bore holes, the classification of rock mass quality has been calculated using the BQ system, RMR and GSI classifications. For the assessment of rock conditions from the results of face mapping in this paper using the RMR and GSI classifications.

Observations from 16 drilling points show the following data:

1. The volcanic breccias of the Qob Formation with relatively in broken conditions, this may be due to the level of weathering and the composition of the grain supported which is pebble to boulder, but fragments of boulder from andesite rocks are still visible. 
2. The laharic breccias of the Qob Formation generally have better core conditions with the composition generally in the form of a supported matrix with the size of the fragments in the form of cobble-pebble so that they are still recorded intact in the drilling data.

3. At one of the drillings location, it was identified the presence of lava in the form of igneous andesite rocks between the layers of volcanic breccia, this can be seen from the condition of the core samples which are generally massive with a thickness of more than 1 meter at the tunnel elevation.

Observations from the 4 face mapping locations only show the constituent rocks of the Mdm Formation which show lithology in the form of massive shale without sandstone intercalated with very clear fissure plane, then there are sandstones with high brittle intensity (Fig. 8).

Calculation of rock mass quality data from 16 bore holes at tunnel elevation and from the results of face mapping shows that the tunnels are in a very poor dominant rock mass condition in $\mathrm{Mdm}$ or Qob formations, but in some locations there are still good to fair rock conditions at the Qob Formation is generally in the form of laharic breccias and andesite lava inserts, while the Mdm formation is in the form of sandstones with a few siltstone intercalation (Table 1). The position of the rock based on the results of face mapping is relatively similar position with the surface outcrops. The strike direction relative to the west-east and the dip angel is between $30^{\circ}-60^{\circ}$, this is used to make geological models and subsurface geology (Fig. 8). Existing data, the model of subsurface geological and engineering geological conditions can be seen in Figure 9.
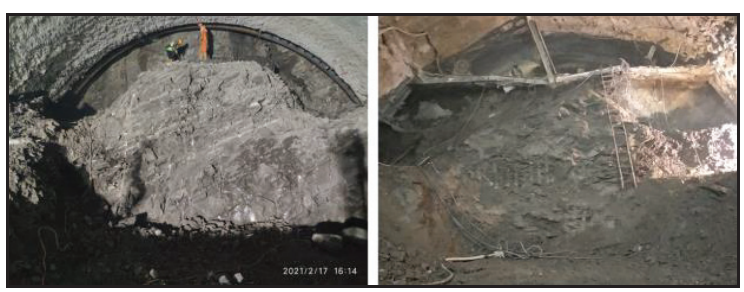

Fig. 8. Excavation face condition from tunnel 6, location measured the rock mass classification from GSI and Q system, left location face mapping 1 and right loaction face mapping 4

\section{Data evaluation}

Based on surface and subsurface data such as constituent lihology, geological structure and an assessment of the quality of the existing rock mass, analysis can be carried out to evaluate the possibility of empirical models of the support system, excavation methods and standup time or the ability of the tunnel opening to be stable during the installation of the support system.

\subsection{Stand-up time}

In determining the stand-up time of 16 drilling data at tunnel elevation using GSI values which are correlated using 3 equations, this is done to obtain the average value of the equation to validate so that the value is not too high or too low in the design. E. Hoek and Brown[18] stated, that the correlation between RMR89 and GSI can be done provided that the value of groundwater conditions is in a dry position, the value for the orientation of the discontinuous plane is considered 0 and this equation is suitable for GSI values $>25$, the equation used is:

$$
G S I=R M R-5
$$

Because generally the rock conditions in the study area have a low GSI value or GSI $<25$, this paper adopts the equation proposed by Osgoui and Ünal[19]. This equation is considered suitable for low GSI or GSI $<25$ values and this equation is obtained from sedimentary rocks such as siltstone, clay to shale, the equation is as follows:

$$
G S I=6 e^{0.05 R M R}
$$

The next equation from Ceballos., et al[20], where this equation has a value of $\mathrm{R} 2=0.89$ or close to 1 . The value of $\mathrm{R} 2$ or the coefficient of determination which simply reflects the value that is getting closer to 1 is a good value reflecting that the $\mathrm{x}$-axis coefficient affects directly with the $y$ axis, the equation is as follows:

$$
G S I=1.13 R M R-11.63
$$

Whereas the RMR89 value from face mapping is not correlated and obtained from direct measurement results, the RMR89 correlation value and the RMR89 value from the face mapping measurement results can be seen in the Table. 1 .

After obtaining the average RMR89 value from 3 correlation equations or direct measurements, the method used to estimate stand-up time is to use the rock mass classification curve from Bieniawski[7] with the technical aspects used, namely: RMR89 value, span dimension and based on data The design span dimension is 13 meters.

Based on the modeling results at stand-up time using plotting on the rock mass classification curve from Bieniawski[7], drill point 2280 has an estimated stand-up time of up to 63 days, drill point 203 is estimated to be 27 days, drill point 440 is estimated to be 13 days while 12 drill points another showed a stand-up time of less than 2 days until collapsing immediately after the excavation began (Fig. 10). The result of face mapping data showed the stand-up time value is low and and can collapse immediately when excavation is carried out (Table. 2). 

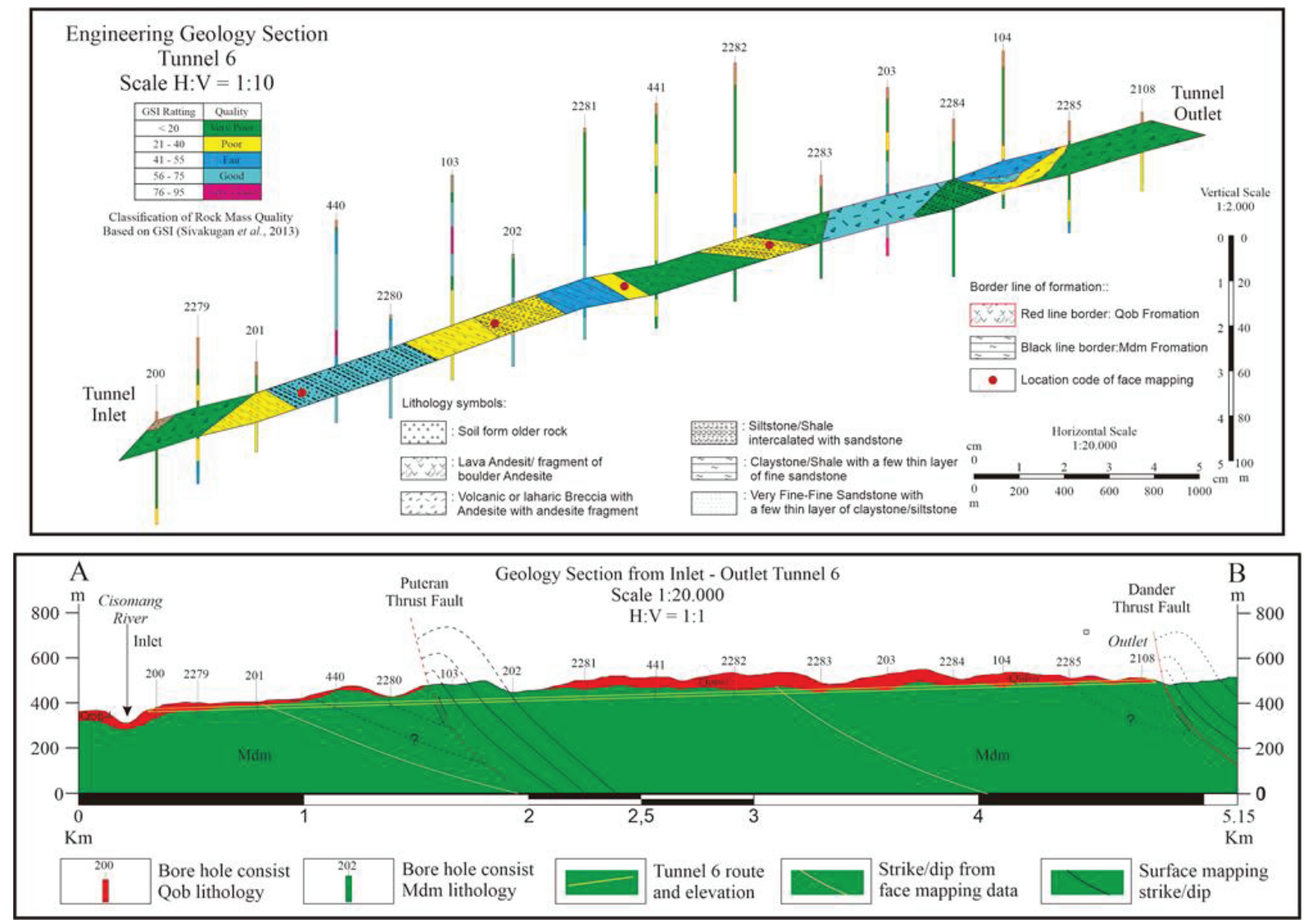

Fig. 9. Cross section model of engineering geology (above) and geological cross section model (below).

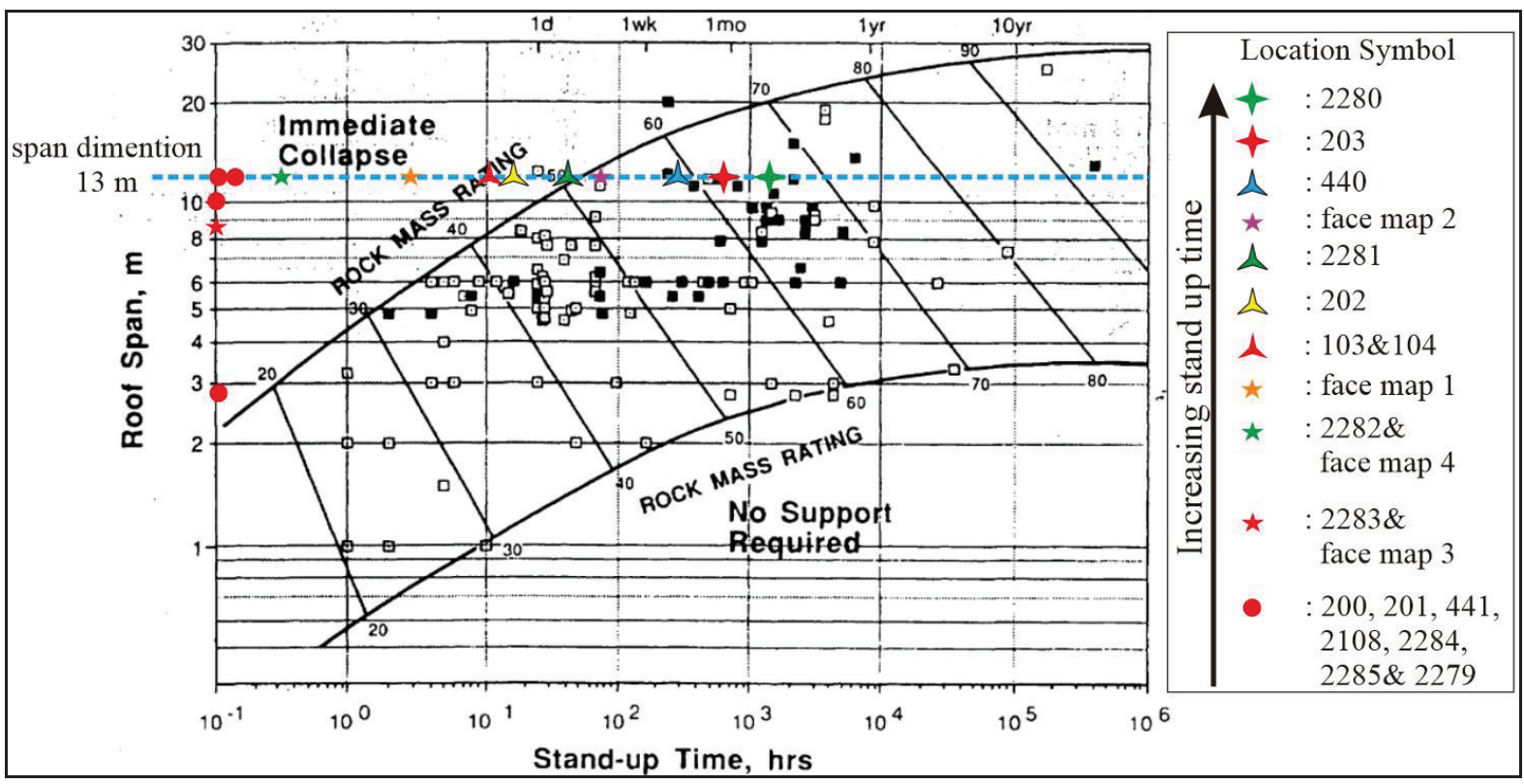

Fig. 10. The results of plotting the RMR value on the Bieniawski stand-up time chart[7]. 


\begin{tabular}{|c|c|c|c|c|c|c|c|c|c|c|c|c|c|c|}
\hline \multirow{2}{*}{ 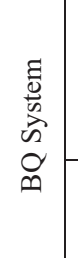 } & 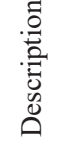 & 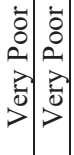 & 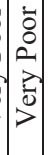 & 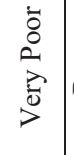 & 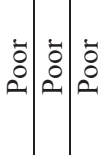 & $\stackrel{\square}{\circ}$ & 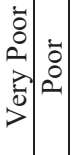 & 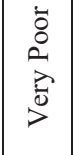 & 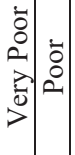 & $\begin{array}{l}\dot{0} \\
\dot{0} \\
0\end{array}$ & 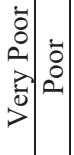 & 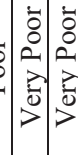 & 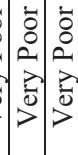 & \\
\hline & $\begin{array}{l}\frac{\tilde{g}}{\tilde{d}} \\
\frac{\vec{g}}{U}\end{array}$ & & $1>$ & $>$ & $\geq \geq \geq$ & $\geq$ & $>\geq$ & $>$ & $>\geq$ & $\geq$ & & & $>$ & \\
\hline \multirow{2}{*}{ 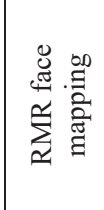 } & 总 & & & ¿̆ & & 离 & & 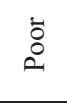 & & 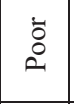 & & & & \\
\hline & 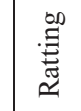 & & & ले & & $\tilde{n}$ & & $\bar{\sim}$ & & ते & & & & \\
\hline \multirow{2}{*}{ 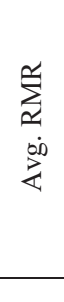 } & 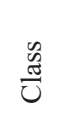 & 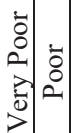 & 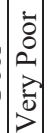 & & : & & 勏考 & & 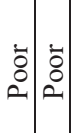 & & 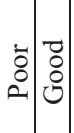 & $\mid \begin{array}{ll}b \\
b\end{array}$ & 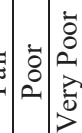 & \\
\hline & $\frac{\mathscr{0}}{\frac{\Xi}{\pi}}$ & $=\lesssim$ & $\sigma$ & & in 67 & & to & & $৯ ৯$ & & $\vec{\sim} \mathcal{S}$ & $\approx \exists$ & $\approx \simeq$ & \\
\hline \multirow{3}{*}{ 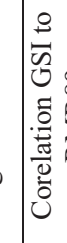 } & 뫼으 & $=\stackrel{\rho}{m}$ & -6 & & $\Leftrightarrow 57$ & & gan & & $\widehat{\sim} \approx$ & & $\underset{\sim}{\Delta} \infty$ & 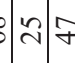 & $\hat{\imath}=$ & \\
\hline & 멍 & $+\stackrel{N}{*}$ & - & & f) & & $q)$ & & $\approx$ & & & $\vec{\nabla}$ & $\approx n$ & \\
\hline & 뫼 & $\leadsto \hat{\sim}$ & $=$ & & $58 \%$ & & ga & & $\grave{\lambda} \curvearrowright$ & & 규 & $\therefore ี$ & $\vec{A}=$ & \\
\hline $\begin{array}{l}\vec{y} \\
0 \\
w \\
\tilde{U} \\
\vec{U}\end{array}$ & 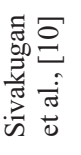 & 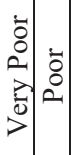 & 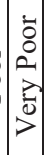 & ڤे & 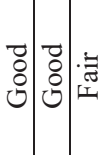 & 范 & : & 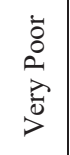 & 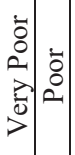 & $\stackrel{\circ}{\circ}$ & 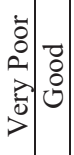 & 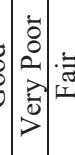 & 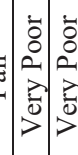 & \\
\hline \multirow{2}{*}{$\vec{\mho}$} & 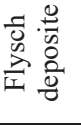 & & & q & & $\tilde{m}$ & & กิ & & $\approx$ & & & & $\frac{\vec{d}}{\sqrt{5}}$ \\
\hline & 意 & $\infty \approx$ & & & C) & & $+\vec{n}$ & & $=\Delta$ & & & $=7$ & & لَّ \\
\hline \multirow{2}{*}{$\begin{array}{l}\text { 豆 } \\
\text { 言 } \\
\text { مू }\end{array}$} & $\stackrel{\circ}{\ominus}$ & $\simeq 7$ & $\widehat{\imath}$ & \&్ల & $\stackrel{\infty}{\curvearrowright} \mid \infty$ & $\cong$ & ๓ & $\infty$ & $\infty \approx$ & $\kappa$ & 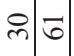 & 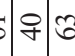 & $\triangle 4$ & 29 \\
\hline & 居 & $\nabla \vec{m}$ & \pm & $=$ & 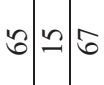 & 8 & $\approx \widehat{6}$ & $\therefore$ & $\therefore \curvearrowright$ & $\infty$ & $=\stackrel{\infty}{+}$ & $\hat{\sim}$ & $=\operatorname{nn}$ & : \\
\hline \multicolumn{2}{|c|}{ 鸹 } & 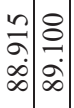 & 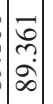 & $\begin{array}{l}\infty \\
\stackrel{7}{4} \\
\stackrel{\infty}{\infty}\end{array}$ & $\begin{array}{l}2 \\
\vdots \\
\infty \\
\infty\end{array}$ & 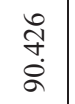 & 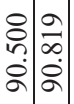 & $\begin{array}{l}\ddot{\infty} \\
\stackrel{0}{+} \\
\stackrel{a}{\sigma}\end{array}$ & 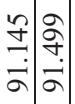 & $\mid \begin{array}{l}0 \\
\dot{b} \\
\dot{a} \\
\vdots\end{array}$ & 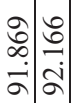 & 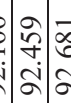 & 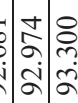 & 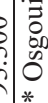 \\
\hline \multicolumn{2}{|c|}{ 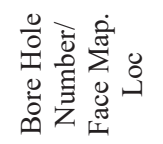 } & $\stackrel{\sim}{\stackrel{\sim}{ล}}$ & & 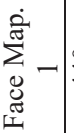 & \&) & 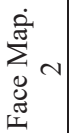 & ते & 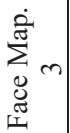 & 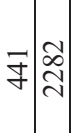 & 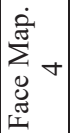 & 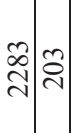 & ầ & 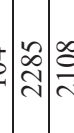 & 車 \\
\hline \multicolumn{2}{|c|}{ 哥 } & 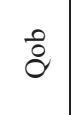 & & \multicolumn{7}{|c|}{$\bar{\Sigma}$} & $\stackrel{\circ}{\circ}$ & $\frac{\xi}{\bar{n}}$ & $\stackrel{\circ}{\circ}$ & 离 \\
\hline
\end{tabular}


Table 2. Summary of stand-up time based on RMR[7] and excavatabilitybased on modifed GSI chart[21]

\begin{tabular}{|c|c|c|c|c|c|c|c|c|}
\hline \multirow{2}{*}{$\begin{array}{c}\text { Bore Hole } \\
\text { Number/ } \\
\text { Face } \\
\text { Mapping } \\
\text { Location }\end{array}$} & \multirow[b]{2}{*}{$\begin{array}{c}\text { Rock } \\
\text { Formation }\end{array}$} & \multicolumn{3}{|c|}{ RMR } & \multicolumn{2}{|c|}{ GSI } & \multirow[b]{2}{*}{$\begin{array}{c}\text { Estimated } \\
\text { Point } \\
\text { Load }^{*}\end{array}$} & \multirow[b]{2}{*}{ Excavability } \\
\hline & & Ratting & Class & $\begin{array}{l}\text { Estimated } \\
\text { standup time }\end{array}$ & Value & Quality* & & \\
\hline 200 & \multirow{2}{*}{ Qob } & 11 & $\begin{array}{l}\text { Very } \\
\text { Poor }\end{array}$ & \multirow{3}{*}{$\begin{array}{l}\text { Immediate } \\
\text { collapse }\end{array}$} & 8 & \multirow{3}{*}{$\begin{array}{l}\text { Very } \\
\text { Poor }\end{array}$} & R2 & \multirow{3}{*}{ Digging } \\
\hline 2279 & & 27 & Poor & & 20 & & R3 & \\
\hline 201 & \multirow{12}{*}{ Mdm } & 9 & $\begin{array}{l}\text { Very } \\
\text { Poor }\end{array}$ & & 6 & & R2 & \\
\hline Face Map. 1 & & 39 & Poor & $1 \mathrm{hrs}$ & 40 & Poor & \multirow{4}{*}{ R3 } & Ripping \\
\hline 440 & & 59 & Fair & \pm 13 days & 62 & \multirow{2}{*}{ Good } & & Hydrolic \\
\hline 2280 & & 61 & Good & \pm 80 days & 64 & & & Breaker \\
\hline 103 & & 44 & \multirow{4}{*}{ Fair } & $\pm 10 \mathrm{hrs}$ & 40 & Fair & & Ripping \\
\hline Face Map. 2 & & 53 & & \pm 3 days & 32 & Poor & \multirow{3}{*}{ R2 } & Digging \\
\hline 202 & & 46 & & $\pm 20 \mathrm{hrs}$ & 44 & \multirow{2}{*}{ Fair } & & \multirow{2}{*}{ Ripping } \\
\hline 2281 & & 51 & & \pm 2 days & 51 & & & \\
\hline Face Map. 3 & & 21 & \multirow{5}{*}{ Poor } & \multirow{5}{*}{$\begin{array}{l}\text { Immediate } \\
\text { collapse }\end{array}$} & 20 & Very & R1 & \multirow{5}{*}{ Digging } \\
\hline 441 & & 25 & & & 19 & Poor & K1 & \\
\hline 2282 & & 29 & & & 24 & Poor & R2 & \\
\hline Face Map. 4 & & 29 & & & 25 & 1001 & K2 & \\
\hline 2283 & \multirow[b]{2}{*}{ Qob } & 21 & & & 15 & V. Poor & R3 & \\
\hline 203 & & 62 & Good & \pm 27 days & 65 & Good & R4 & $\begin{array}{c}\text { Hydrolic } \\
\text { Breaker }\end{array}$ \\
\hline 2284 & Mdm & 23 & Poor & $\begin{array}{l}\text { Immediate } \\
\text { collapse }\end{array}$ & 17 & $\begin{array}{l}\text { Very } \\
\text { Poor }\end{array}$ & $\mathrm{R} 1$ & Digging \\
\hline 104 & \multirow{3}{*}{ Qob } & 44 & Fair & $\pm 10 \mathrm{hrs}$ & 41 & Fair & R2 & Ripping \\
\hline 2285 & & 25 & Poor & \multirow{2}{*}{$\begin{array}{l}\text { Immediate } \\
\text { collapse }\end{array}$} & 19 & \multirow{2}{*}{$\begin{array}{l}\text { Very } \\
\text { Poor }\end{array}$} & R1 & \multirow[b]{2}{*}{ Digging } \\
\hline 2108 & & 12 & $\begin{array}{l}\text { Very } \\
\text { Poor }\end{array}$ & & 8 & & R1 & \\
\hline
\end{tabular}

*: Sivakugan et al., [10], **: Hoek., et al[5], \#: Tsiambaos and Saroglou[21].

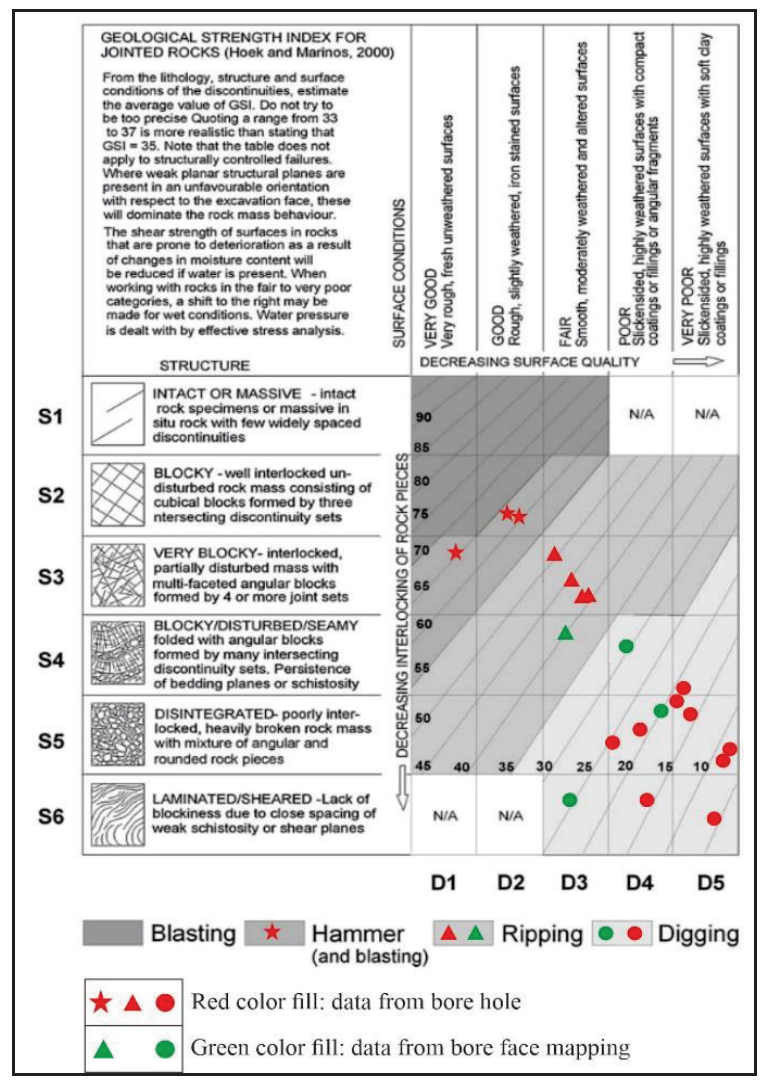

Fig. 11. The excavation method based on Tsiambous and Saroglou graphic chart for Is $<3 \mathrm{MPa}[21]$ 


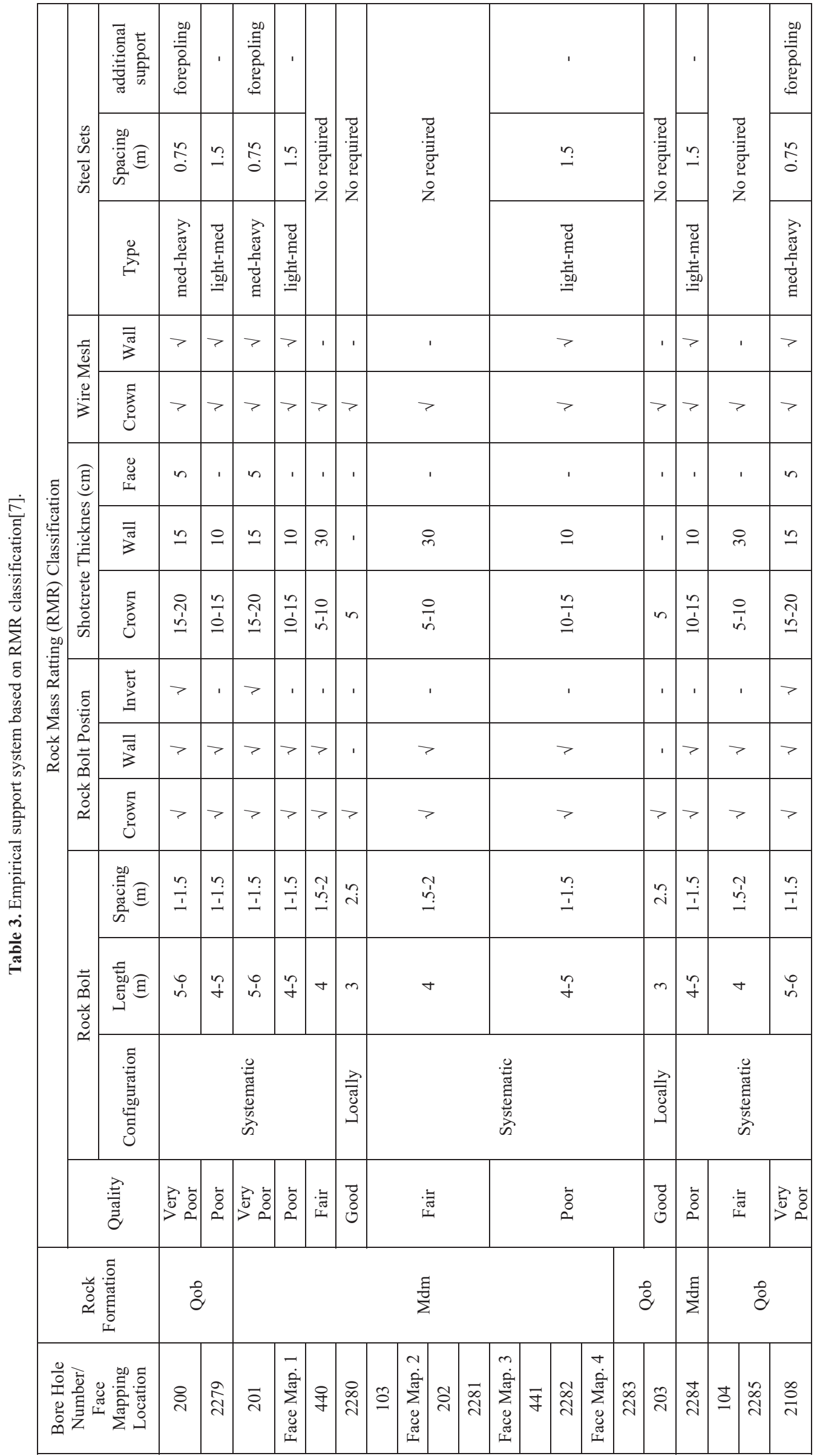




\subsection{Excavatability}

In evaluating the selection of an effective excavation type it is important to consider the physical, mechanical and behaviour characteristics of the geomaterial to be excavated[21]. In this study, the evaluation of the selection of the type of excavation method refers to the GSI value of the rock mass at the tunnel elevation and the rock strength value from the direct test results using the classification of Hoek., et al[5].

GSI values and rock strength values from the direct test results will be plotted on the GSI chart of the excavatability assessment of a rock mass from G. Tsiambaos \& H. Saroglou[21]. The plotting results can be seen in Figure 19. The selection of the type of excavation method based on the plot results is dominated by the digging method, ripping at 4 drilling locations and 1 face mapping location, while the hammer breaker method can be carried out at three drilling point locations (Fig. 11).

\subsection{Support system}

To determine the type and dimensions of the support system in this study, it refers to the average RMR correlation value from the analysis of 16 core samples and the RMR value from the direct measurement results at 4 face mapping locations. The results of the analysis showed 12 locations with very poor to poor quality, 6 locations with fair quality and 2 locations with good quality based on the RMR classification. Empirical support system design based on RMR for very poor-poor rock mass quality is a combination of rockbolt, shotcrete and steel sets, while for rock mass conditions fair-good steel sets are not required (Table 3). The approach to determining the empirical support system based on the RMR value was chosen because this classification provides details of the dimensions, spacing and configuration of the support system for tunnel construction.

\section{Discussion}

To build subsurface models, the bedding plane of surface outcrops is very useful in calibrating the model that was formed. The interpretation of the subsurface geological structure uses calibration from the position of the surface area assisted by the position of the bedding plane on face mapping measurements such as the reconstruction of the Dander thrust fault and the Puteran thrust fault, this is also supported by drill data at drill location 103 which shows the relative poor rock mass quality this is indicated due to the influence of the position of the drill location 103 is on the hanging wall of the Puteran thrust fault.

The surface outcrops conditions at several locations are quite helpful in providing an interpretive model of the rock mass conditions below the surface, especially in the Qob formation in the form of volcanic breccia and lava. The surface outcrops are also useful in calibrating rock mass quality assessments, especially in terms of calculating the value of subsurface GSI classification.

The BQ classification system used in the construction of this tunnel shows a more conservative rock mass quality compared to the other two classifications. On the other hand, the $\mathrm{BQ}$ rock mass classification system is a relatively new classification used in Indonesia. Therefore, in this study, other classifications such as GSI and RMR are used to obtain a more comprehensive assessment of the rock mass quality in this tunnel. Each rock mass classification has its own limitations and advantages so that the use of more than one classification is very useful to complement each other and provide additional information in tunnel construction. There are three aspects that are evaluated in this paper that is the standup time value, the type of excavation method and the empirical support system, which are the basic things needed in the early stages of tunnel construction.

\section{Conclusion}

Based on the engineering geological mapping, evaluation of rock coring, and face mapping, the research conclusions are:

1. The tunnel construction area consisted of volcanic breccia, laharic breccia, and andesite lava of the Qob formation, and claystone, marl, and calcareous shale with intercalated sandstones of the $\mathrm{Mdm}$ formation.

2. The sedimentary rock masses of the Mdm formation along the tunnel route had relatively poor to very-poor quality.

3. The stand-up time of the sedimentary rock masses is relatively low, implying reinforcement is necessary before excavation. The stand-up time of the andesite lava is higher than that of the rock masses of the Mdm formation, while the volcanic breccia and laharic breccias can collapse immediately during excavation.

4. The excavation method based on evaluation using GSI values and compressive strength from the direct field test results show that for sedimentary rocks the conventional excavation method can still be applied, while the Qob formation in andesite lava and breccia with good quality is more suitable to use a ripper and hydraulic breaker.

5. Empirical support system design based on RMR for very poor-poor rock mass quality is a combination of rockbolt, shotcrete and steel sets, while for rock mass fair-good conditions steel sets are not required.

6. The excavation methods and supports systems proposed in this study can change during tunnel construction process because the empirical models proposed in this study are developed with limited data. 
The authors wish to express deep gratitude to PT. Kereta Cepat Indonesia China (PT. KCIC), High Speed Railway Consortium Company (HSRCC), China Railway Engineering Corporation (CERC), and China Railway Design Corporation (CRDC) for the permission to do this research and publish the site investigation data. Financial support from The Ministry of Public Works and Housing of Indonesia is gratefully acknowledged.

\section{References}

1. Sudjatmiko. Geological Map of The Cianjur Quadrangle (2003)

2. M. Genis, H. Basarir, A. Ozarslan, E. Bilir, E. Balaban, Eng. Geol. 92(1), 14-26 (2007)

3. ISRM. ISRM suggested methods for Rock characterisation, testing and monitoring (Pergamon Press, New York, 1981)

4. Bakosurtanal. West Java Province Map (2003)

5. E. Hoek, P.K. Kaiser, W.F. Bawden. Support of Underground Excavations in Hard Rock (CRC Press, 2000)

6. State Railway Administrator. TB 10003 - 2016/J 449 - 2016: Code for Design of Railway Tunnel. Beijing (2016)

7. Z.T. Bieniawski. Engineering rock mass classifications: a complete manual for engineers and geologists in mining, civil, and petroleum engineering. 1st ed. (John. Wiley and Sons, New York, 1989)

8. P. Marinos, E. Hoek. GSI: A geologically friendly tool for rock mass strength estimation, in ISRM Int Symp (2000)

9. E Hoek, T.G. Carter, M.S. Diederichs. Quantification of the geological strength index chart, in 47th US Rock Mech/Geomech Symp (2013)

10. N. Sivakugan, S.K. Shukla, B.M. Das. Rock Mechanics An Introduction. (Taylor \& Francis Group, New York, 2013)

11. V. Marinos, T.G. Carter, Eng. Geol. 239, 282-297 (2018)

12. S feng. Guo, S wen. Qi, C. Saroglou. Journal of Central South University 27, 3090-3102 (2020)

13. B. Singh, R.K. Goel. Engineering Rock Mass Classification Tunneling, Foundations, and Landslides Bhawani (Elsevier, 2011)

14. P. Marinos, V. Marinos, E. Hoek. Geological Strength Index (GSI). A characterization tool for assessing engineering properties for rock masses, in Proceeding Underground Work under Special Condition (2007)

15. Abdurrokhim. Bull. Sci. Contrib. Geol, 15 No.2 (2017)

16. A. Bouma. Development in Sedimentology 3, 247-256 (1964)

17. A.H. Satyana, M.E.M. Purwaningsih. Structural Curvature of Central Java: A Horizontal Fault Segmentation, in Proceeding of IAGI (Ikatan Ahli Geologi Indonesia), 1-14 (2002)
18. E. Hoek, E.T. Brown. Int. J. Rock Mech. Min. Sci. 34, 1165-1186 (1997)

19. R. Osgoui, E. Ünal. Rock reinforcement design for unstable tunnels originally excavated in very poor rock mass, in Proceeding 31st ITA-AITES World Tunnel Congress (2005)

20. F. Ceballos, C. Olalla, R. Jiménez. Relationship between RMRb and GSI based on in situ data, in ISRM Eur Reg Symp, Vigo, Madrid (2014)

21. G. Tsiambaos, H. Saroglou, Bull. Eng. Geol. Environ. 69(1), 13-27 (2010) 